\title{
INSPIREE:
}

\section{Physical Fitness and Learning Achievement Academic in Children Aged $10-12$ years}

doi https://doi.org/10.53905/inspiree.v2i2.51

*Herli Pardilla ${ }^{1 a b c d e}$ [D

${ }^{1}$ Physical Education Education, Universitas Pahlawan Tuanku Tambusai, Riau, Indonesia.

The purpose of the study. The purpose of this study was to determine how big the impact of physical fitness on student achievement

Materials and methods. The method in this research is a path analysis method with a correlational test technique. Correlational refers to taking the rsquare hypothesis, which is how big the impact of the correlation between physical fitness and student learning achievement is and this study uses the SPSS Version 25 application.

Results. The results found that the level of the variable physical fitness on learning achievement with $r=0.708$ with rsquare $=0.501$ Coefficients sig value .0 .000 . It turns out that the value of sig. 0.000 is less than the probability value of 0.00 or the value of $0.05>0.000$.

Conclusions. . then $\mathrm{Ha}$ is accepted and $\mathrm{HO}$ is rejected, meaning that the path analysis coefficient is significant. This study proves that there is a direct impact of physical fitness on student achievement.

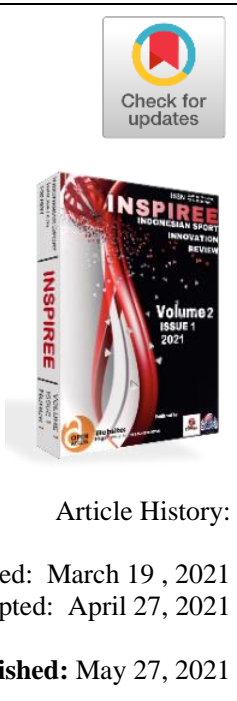

Keywords: student achievement; physical fitness

Received: March 19,2021

Accepted: April 27, 202

Published: May 27, 202

\section{INTRODUCTION}

Evaluation of learning achievement is marked by changes in student behavior through the educational process. The changes referred to in the form of changes in knowledge, skills, habits, attitudes, understanding, appreciation, interests, adjustments and all aspects of a person's organism or personality. Maintenance of physical activity that improves health and performance-oriented behavior in exercise (Beauchamp et al., 2019). A high-quality evaluation system certifies, provides a basis for individual improvement, and ensures that all students receive a fair assessment so as not to limit current and future student opportunities. From some of the above understanding shows that learning can change a person's behavior, the change occurs due to the experience and exercises carried out by the learner. Learning is a constructive process

*Corresponding Author Herli Pardilla, e-mail: herlipardilla@gmail.com

Authors'Contribution: a-Study design; b-Data collection; c-Statistical analysis; d-Manuscript preparation; e-Funds collection. 
Physical Fitness and Learning Achievement Academic in Children Aged 10-12 years.

of constructing meaning that produces reflective abstractions that produce symbols in a medium (Fosnot \& Perry, 1996). The learning process leads to the mastery of knowledge, skills, habits or attitudes, all of which are acquired, stored and implemented, resulting in a progressive and adaptive level of behavior resulting in achievement in learning.

Poor student achievement in science is a global challenge (Ogunleye \& Ojo, 2019). In the learning process, students or students experience various problems in achieving their learning achievements. There are children who often get satisfactory achievements and others who do not. Of course, there are many factors that affect children's learning, so that it will have an impact on their achievement. One of the internal factors of the physical fitness of the child is one of the factors that determine learning achievement in children. So it is an important component in students' academic success (Grissom, 2005).

Excellent physical health will support a student to carry out learning activities well. Providing appropriate Physical Activity interventions, students can significantly improve academic achievement (Alvarez-Bueno et al., 2017) so that they will be able to achieve good learning achievements. On the other hand, a student who is sick, especially when his condition is very severe and must be treated intensively in the hospital, cannot concentrate on studying well. Of course he will not be able to achieve good learning achievement and can even result in learning failure. There are even educators who do not know how to make their students get satisfactory achievements. Children's growth and development is strongly influenced by the physical fitness of children.

Good physical fitness will affect student learning activities, because students will be more enthusiastic in participating in the learning process and always ready to accept the material provided by the teacher. Increased physical activity and fitness may also be associated with better academic performance in children (Eveland-sayers et al., 2009). Children who participate in specially designed physical activity programs score better on the final assessment than children (Golubović et al., 2012). Physical fitness is closely related to the cardiovascular system, in short, high cardiorespiratory fitness 
Physical Fitness and Learning Achievement Academic in Children Aged 10-12 years.

plays an important role in improving the health of children and adolescents and academic achievement (Marques et al., 2018).

Physical fitness or good physical condition of students will enhance the ability and willingness to learn. Physical education in schools needs to be developed so that students are not only physically and spiritually healthy (Apriyano et al., 2020). The level of a person's physical fitness will affect the readiness or physical and mental ability to accept the workload (learning activities) which are the obligations of students every day. Children who are fit have a considerable advantage in test scores, and there is an achievement gap between fit and unfit youths during their academic careers (London \& Castrechini, 2011). Monitoring the development of physical fitness is also very important to do, because the results of this monitoring can be used as an evaluation tool for students to improve and improve the physical learning process and as a basis for assessing the success of the physical learning process by a physical education teacher at school.

Physical fitness is closely related to human activities in doing work and moving. Physical fitness is needed to support a person's daily activities so that these activities are optimal. However, obtaining lecture materials may not be effective if the student feels tired and recovery is slow. Therefore, learning some practical movements requires good coordination (Kriswanto et al., 2019). Agus Mukhlolid (2004) states that physical fitness is the ability to do work or activities, enhance work power with or without experiencing significant or excessive fatigue. So it can be concluded that physical fitness is the body's ability to mobilize and adjust the function of the components of the body's organs within physiological limits to environmental conditions or physical work efficiently without significant fatigue. Not fit one's body will affect the quality and quantity of one's body performance. This is characterized by the presence of the body easily tired and the body's response to wanting to rest which results in sleepy eyes that affect the results of one's body performance (Schleicher et al., 2008). Likewise with learning performance in learning, students who are not fit will feel tired in following learning. this is because the body is not fit in carrying out learning which has implications for the low learning achievement of students (Gonzalez et al., 2011). 
Physical Fitness and Learning Achievement Academic in Children Aged 10-12 years.

As for the theory, Suratman (1975) physical fitness is a physical aspect of overall

fitness (total fitness) that gives a person the ability to lead a very productive life and can adapt to any appropriate physical load or stress. Someone who has good physical fitness can be interpreted as having enough ability to do his job efficiently without causing significant fatigue, so that he still has energy left to fill his spare time and other sudden tasks.

\section{MATERIALS AND METHODS}

Design of the Study

The research method used in this study is a quantitative approach, survey method with measurement and test techniques. While the analysis technique uses a path analysis method, namely research that will examine or analyze the relationship between research variables, and measure the direct effect of one variable on other variables. So, the path analysis model is used to analyze the pattern of relationships between variables with the aim of knowing the direct or indirect effect of a set of independent variables (exogenous) on the dependent variable (endogenous). The variables studied consisted of four variables consisting of exogenous (free) variables and one endogenous (bound) variable. Exogenous variable Endurance $(X)$ Endogenous variable consists of learning achievement $(Y)$.

\section{Population and Sampling Procedure}

In this study, the target population of the study were all male students who participated in sports clubs with reference to the value of learning outcomes for physical education in elementary schools. With the age category of 8-12 years, there are 250 students.

\section{Data Collection Tools/Research Instrument}

Learning Achievement Test Instruments

An instrument to measure the level of learning achievement by looking at the average value of the report cards of students participating in sports in Pulau Jambu village. In taking the physical education learning achievement test using the average value of students' academic achievements in 3 months.

Physical Fitness Test using Bleep Test

The measuring instrument used to measure the level of physical fitness of the subject is a physical fitness test using the Bleep Test. Bleep Test is a test used to determine a person's level of physical fitness. The procedure for carrying out the test 
Physical Fitness and Learning Achievement Academic in Children Aged 10-12 years.

is by listening to the Bleep Test audio test to test participants and following the test procedure by running between tracks with time guidelines that have been extracted into the audio bleep test.

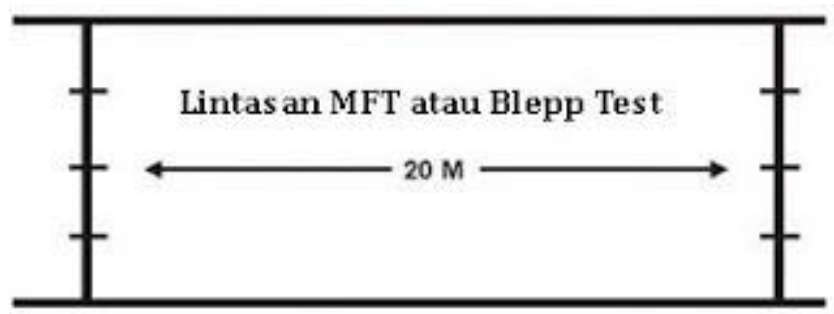

Figure 1. Test trajectory in implementation in measuring physical fitness kebugaran

This test is a series of tests where all test items must be carried out in one unit of time and in taking the fitness test a period of 1 time in 1 week is taken.

Data Analysis

In this study using data analysis criteria using analysis requirements and hypothesis-testing. Requirements for data analysis using normality test, and data homogeneity test. Furthermore, in testing the hypothesis in research from the results of data analysis with product moment correlation, this test was conducted to determine the level of relationship between physical fitness and student achievement. After the correlation index number (rxy) is obtained, further analysis is carried out, namely by providing an interpretation or interpretation of the rxy value based on the Rsquare value, which means that the impact value of the physical fitness variable on students' physical education learning achievement.

\section{RESULTS}

\section{Description of data}

The description of the data from the results of the study aims to provide a general description of the distribution of data distribution, both in the form of the size of the location of the frequency distribution. Prices are presented after being processed from raw data using descriptive statistical methods, namely the maximum value, minimum value, range, average, standard deviation and variance. The summary of the results of statistical calculations is as follows: 


\begin{tabular}{ccc}
\hline Statistic & \multicolumn{2}{c}{ Variable } \\
\cline { 2 - 3 } & $\mathbf{X}$ & $\mathbf{Y}$ \\
\hline Jumlah Sampel $(\mathrm{n})$ & 50 & 50 \\
Jumlah Nilai & 377 & 3951 \\
Mean & 7,54 & 79,02 \\
SD & 0.36 & 8,47 \\
Var & 0.13 & 71,69 \\
max & 8,00 & 100 \\
Min & 6,50 & 60 \\
Range & 1,50 & 40 \\
\hline
\end{tabular}

Information:

$X$ : Physical Fitness

$Y:$ Student achievement

\section{Data Analysis Requirements}

Normality test $x$

Based on the results of the Liliefors normality test calculation, the LO value is 0.1117. Where the critical value of LO in the liliefors table for the sample size $(n)=50$ with $a=0.05$ obtained a value of 0.12529 . When compared, the calculated $L_{0}$ value is smaller than the table LO, so it can be concluded that the $\mathrm{X}$ normality test is normally distributed.

Normality test $Y$

Based on the results of the Liliefors normality test calculation, the $L_{0}$ value is 0.1192. Where the critical value of LO in the liliefors table for the sample size $(n)=50$ with $a=0.05$ obtained a value of 0.12529 . When compared to the calculated $L_{0}$ value, it is smaller than the table LO, so it can be concluded that the $\mathrm{Y}$ normality test is normally distributed.

\section{Linearity Test}

Regression linearity test analysis was carried out to test the relationship between variables, namely fulfilling the requirements that these variables must have a linear and regression relationship. For linearity test requirements, if Fcount < Ftable. Meanwhile, to meet the significance of the regression if Fcount $>$ Ftable. The value of the correlation coefficient is a calculation number that states the level of strength of the relationship. The strength of the correlation has an acceptable level of significance if $t$ count $>$ table.

Based on the results of the calculation of the regression linearity test, it was obtained that the $F$ function was -4.101 . Where the critical value of $F_{\text {table }}$ for sample size $(n)=50$ with $F_{\text {table }}$ obtained a value of 19.4740 . If compared to $F_{\text {count, }}$ it turns out to be smaller than $\mathrm{F}_{\text {table, }}$ so it can be concluded that the linearity test of this data is linear regression. 
Physical Fitness and Learning Achievement Academic in Children Aged 10-12 years.

And to test the significant regression with the provisions of $F_{\text {count }}>F_{\text {table, }}$ the regression

test is significant. So with the significant regression test of $X$ against $Y$ there is a tcount of 28.2166 and Ftable is 4.04 so it can be concluded that there is a significant regression

\section{Hypothesis testing}

Individual testing ( $\mathrm{X}$ against $\mathrm{Y}$ ) Physical fitness contributes to student achievement in the village of Pulau Jambu. Individual tests are shown by the Coeficients table, that the path coefficient results $p_{y x}=0.000$

Table 2. Model Summary

\begin{tabular}{|c|c|c|c|c|c|c|c|c|c|c|}
\hline \multicolumn{11}{|c|}{ Model Summary } \\
\hline \multirow[b]{2}{*}{ Model } & \multirow[b]{2}{*}{$\mathrm{R}$} & \multirow[b]{2}{*}{ R Square } & \multirow[b]{2}{*}{$\begin{array}{l}\text { Adjusted R } \\
\text { Square }\end{array}$} & \multirow[b]{2}{*}{$\begin{array}{l}\text { Std. Error of } \\
\text { the Estimate }\end{array}$} & \multicolumn{5}{|c|}{ Change Statistics } & \multirow[b]{2}{*}{$\begin{array}{l}\text { Durbin- } \\
\text { Watson }\end{array}$} \\
\hline & & & & & $\begin{array}{l}\text { R Square } \\
\text { Change }\end{array}$ & F Change & df1 & $\mathrm{df} 2$ & $\begin{array}{l}\text { Sig. F } \\
\text { Change }\end{array}$ & \\
\hline 1 & $708^{a}$ &, 501 &, 501 & 3,35777 &, 501 & 225,724 & 1 & 48 &, 000 & 2,095 \\
\hline
\end{tabular}

From the table above. Coefficients, obtained the value of sig. 0.000 . It turns out that the value of sig. 0.000 is less than the probability value of 0.00 or the value of $0.05>$ 0.000. then $\mathrm{Ha}$ is accepted and $\mathrm{H}_{0}$ is rejected, meaning that the path analysis coefficient is significant. So physical fitness contributes to the learning achievement of students who participate in sports clubs.

\section{DISCUSSION}

The researcher's observations on students who attend sports clubs on the guava island are quite surprising. Sometimes students who take part in sports in the village of Pulau Jambu get good learning achievements and high average scores. On the other hand, students who excel in sports often fail in general learning material. So theoretically, fitness-related references to fitness become some of the problems in research. Physical fitness is an element of physical condition in a certain movement activity as well as the main element in an effort to achieve student achievement. According to Bompa in Syafrudin (2011) defines "Physical fitness as a product of two abilities, namely strength (strength) and speed (speed) to perform maximum force in a fast time". In line with that while James Tangkudung (2012) is power, also called elastic strength, which is the type of strength that is needed where the muscle can move quickly against a resistance and the combination of speed of contraction and speed of movement However the available evidence suggests that physically active and fit 
Physical Fitness and Learning Achievement Academic in Children Aged 10-12 years.

children tend to perform better in class, and that daily physical education does not negatively affect academic performance (Masciotra et al., 2019).

Physical fitness as a driving force when doing a swing on learning achievement. In practice, if an athlete does not have good physical fitness in doing so, it is certain that student learning outcomes will not run optimally and will not be able to learn efficiently. From the results of research that has been carried out on the physical fitness variable in student achievement, it was found that there was a direct effect of physical fitness (X) on learning achievement of 0.821 . This can be seen in the Coffesient Table which shows the value of sig. 0.000 . It turns out that the value of sig. 0.000 is smaller than the probability value of 0.05 or the value of $0.05>0.000$. then the alternative hypothesis $\mathrm{Ha}$ is accepted and the null hypothesis $\mathrm{HO}$ is rejected. It can be interpreted that the path analysis coefficient between physical fitness $(X)$ and learning achievement $(Y)$ has a very significant effect. So it can be concluded that physical fitness has a direct effect on student achievement. The test results show that strength or more specifically physical fitness is the dominant element of physical ability and has a very significant influence on student achievement. When viewed from the magnitude of the influence of physical fitness found a strong influence that is equal to 0.821 or $82.10 \%$ when tested individually. These findings were also found in several research journals Humaid (2017) which states that, shows that arm muscle strength influences archery achievement, which means that it shows that arm muscle strength affects achievement in archery. The magnitude of the influence of strength on physical fitness is also stated by Donatelli et al., (2000) that this study provides the clinician with a comprehensive profile of range of motion and muscle strength measurements in the pitching and nonpitching arms of professional.

\section{CONCLUSION}

Learning outcomes and high learning achievements make the body tired quickly in understanding learning. In discussing the effect of this physical fitness variable on learning achievement, it is found that this research can be accepted empirically. This statement states that the physical fitness possessed by students is also one of the components of physical ability that is indispensable in improving student achievement. 
Physical Fitness and Learning Achievement Academic in Children Aged 10-12 years.

Thus, in accordance with the hypothesis proposed that there is an effect of physical fitness on learning achievement who participates in sports clubs.

\section{REFERENCES}

Alvarez-Bueno, C., Pesce, C., Cavero-Redondo, I., Sanchez-Lopez, M., Garrido-Miguel, M., \& Martinez-Vizcaino, V. (2017). Academic achievement and physical activity: A meta-analysis. Pediatrics, 140(6). https://doi.org/10.1542/peds.2017-1498

Apriyano, B., Zainuddin, Z. A., \& Hashim, A. H. M. (2020). Physical Fitness of Student at the Junior High School. 460(Icpe 2019), 105-110. https://doi.org/10.2991/assehr.k.200805.030

Beauchamp, M. R., Crawford, K. L., \& Jackson, B. (2019). Social cognitive theory and physical activity: Mechanisms of behavior change, critique, and legacy. Psychology of Sport and Exercise, 42(November), 110-117. https://doi.org/10.1016/j.psychsport.2018.11.009

Eveland-sayers, B. M., Farley, R. S., Fuller, D. K., Morgan, D. W., \& Caputo, J. L. (2009). Physical Fitness and Academic Achievement in Elementary School Children. Journal of Physical Activity and Health, 6, 99-104. http://community.Ihup.edu/beverhar/Fitness and Academic Achievement in Elementary Students_Everand-Sayers, Farley et al. 2009.pdf

Fosnot, C. T., \& Perry, R. S. (1996). Constructivism: A Psychological Theory of Learning. Constructivism: Theory, Perspectives, and Practices, 0, 28. http://rsperry.com/fosnotandperry.pdf

Golubović, Š., Maksimović, J., Golubović, B., \& Glumbić, N. (2012). Effects of exercise on physical fitness in children with intellectual disability. Research in Developmental Disabilities, 33(2), 608-614. https://doi.org/10.1016/j.ridd.2011.11.003

Gonzalez, C., Best, B., Healy, A. F., Kole, J. A., \& Bourne, L. E. (2011). A cognitive modeling account of simultaneous learning and fatigue effects. Cognitive Systems Research, 12(1), 19-32. https://doi.org/10.1016/j.cogsys.2010.06.004 
Physical Fitness and Learning Achievement Academic in Children Aged 10-12 years.

Grissom, J. B. (2005). Physical Fitness And Academic Achievement. Journal of Exercise Physiology, 8(1), 11-25. https://peacefulplaygrounds.com/pdf/right-torecess/fitness-academic-achievement.pdf

Kriswanto, E. S., Setijono, H., \& Mintarto, E. (2019). The effect of cardiorespiratory fitness and fatigue level on learning ability of movement coordination. Cakrawala Pendidikan, 38(2), 320-329. https://doi.org/10.21831/cp.v38i2.24565

London, R. A., \& Castrechini, S. (2011). A longitudinal examination of the link between youth physical fitness and academic achievement. Journal of School Health, 81(7), 400-408. https://doi.org/10.1111/j.1746-1561.2011.00608.x

Marques, A., Santos, D. A., Hillman, C. H., \& Sardinha, L. B. (2018). How does academic achievement relate to cardiorespiratory fitness, self-reported physical activity and objectively reported physical activity: A systematic review in children and adolescents aged 6-18 years. British Journal of Sports Medicine, 52(16), 1039. https://doi.org/10.1136/bjsports-2016-097361

Masciotra, D., Roth, W.-M., \& Morel, D. (2019). Enactive Education. Enaction, 151-154. https://doi.org/10.1163/9789087901004_010

Ogunleye, B. O., \& Ojo, O. R. (2019). Impact of physical fitness activities on students' Basic Science achievement in selected Nigerian secondary schools. Annual Journal of Technical University of Varna, Bulgaria, 3(2), 21-31. https://doi.org/10.29114/ajtuv.vol3.iss2.145

Schleicher, R., Galley, N., Briest, S., \& Galley, L. (2008). Blinks and saccades as indicators of fatigue in sleepiness warnings: Looking tired? Ergonomics, 51(7), 982-1010. https://doi.org/10.1080/00140130701817062 


\section{LAMPIRAN}

\section{Information About The Authors:}

Dr. Herli Pardilla, M.Pd: Email: herlipardilla@gmail.com ;https://orcid.org/0000-0001-67773479; https://www.scopus.com/authid/detail.uri?authorId=57214080181; Department of Physical Education, faculty of Education at Universitas Pahlawan, Indonesia, Tuanku Tambsuai Street, 23, Bangkinang City, 28412, Indonesia. 